\title{
FEATURE Restoration of 2011 flood-damaged Birds Point-New Madrid Floodway
}

\author{
Kenneth R. Olson and Lois Wright Morton
}

D uring the spring 2011 flooding along the Mississippi River, the strong current and sweep of water through the Birds Point, Missouri, levee breach in May of 2011 created a hundred hectares (hundreds of acres) of deep gullies; scoured hundreds of hectares (hundreds of acres) of land; eroded tons of soil; filled ditches with sediment which blocked drainage; created sand deltas; and damaged irrigation equipment, farm buildings, and homes. Reclamation and restoration of these agricultural lands following the US Army Corps of Engineers' (USACE) opening of the New Madrid Floodway to relieve flood pressure on the levee system from the Mississippi River (Camillo 2012; Olson and Morton 2012a, 2012b) has been time consuming and costly to individual landowners and public tax dollars. While levees were rebuilt, ditches cleared of sediment, and many lands in the floodway restored by November of 2012, soil productivity and growing conditions continue to challenge the farmers of this historically highly productive region.

The USACE decision to blow up Birds Point levee along the Lower Mississippi River and flood agricultural lands in the New Madrid Floodway (Missouri) (figure 1) was difficult, with substantive legal challenges as well as social and political trade-offs between human life and property in urban and rural areas (Camillo 2012). The induced breach and flooding of 53,824 ha $(133,000 \mathrm{ac})$ of Missouri farmland resulted in partial 2011 crop loss and permanent soil damage because of land scouring, gully fields, and crater lake areas (Olson and Morton 2012b). The opening of the floodway resulted in a 3.0 to $3.6 \mathrm{~m}$ (10 to $12 \mathrm{ft}$ ) wall of floodwater pouring through the $1.8 \mathrm{~km}(1.2 \mathrm{mi})$ hole in the breached levee and into the floodway with

Kenneth R. Olson is professor of soil science in the College of Agricultural, Consumer, and Environmental Sciences, University of Illinois, Urbana, Illinois. Lois Wright Morton is professor of sociology in the College of Agriculture and Life Sciences, lowa State University, Ames, lowa.

\section{Figure 1}

Map of the Birds Point-New Madrid Floodway located in Missouri and just south of Cairo, Illinois, and the confluence of the Ohio and Mississippi Rivers.

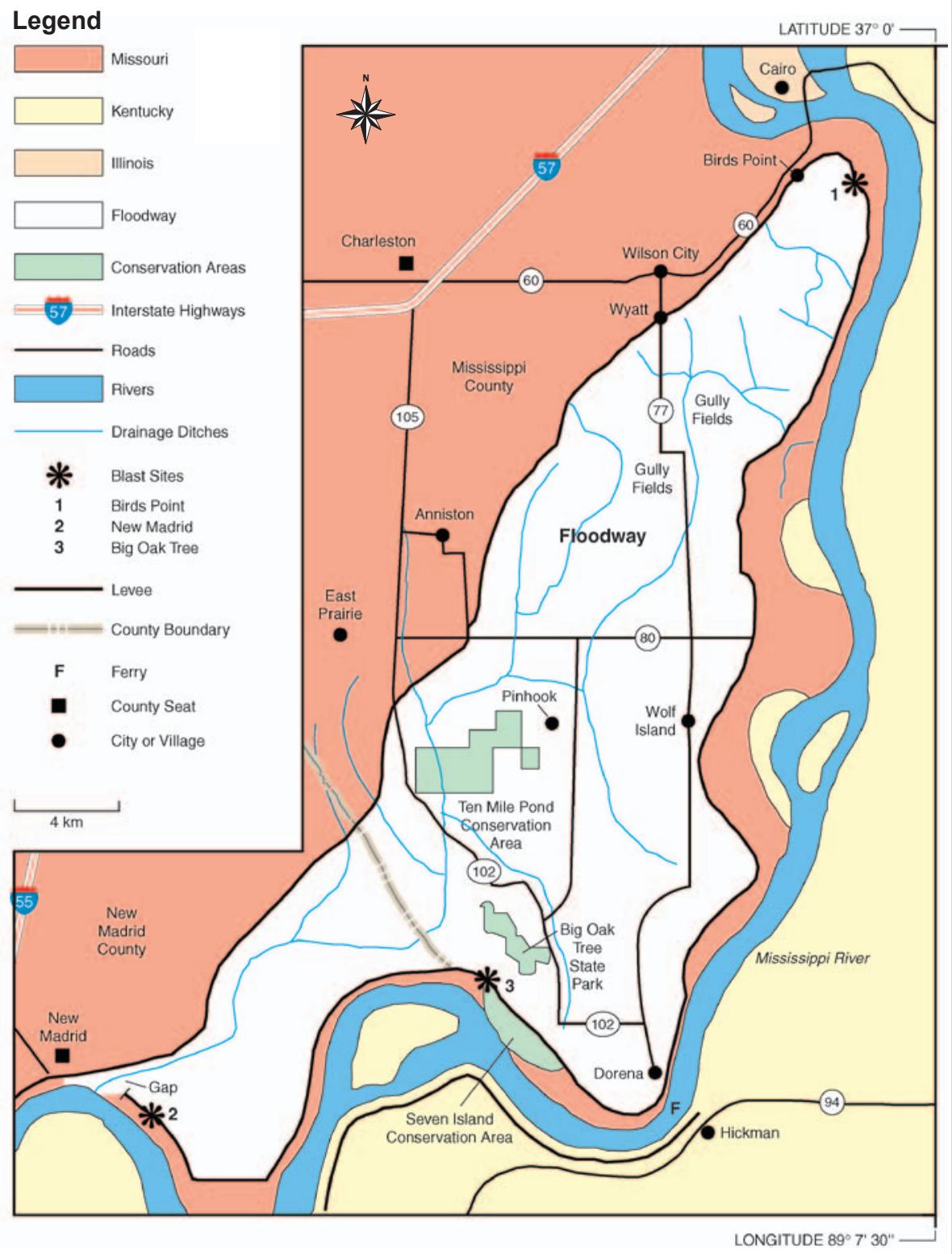

an average width of $8 \mathrm{~km}$ (5 mi), which dropped the initial water depth by onefourth or to 0.8 to $0.9 \mathrm{~m}(2.5$ to $3 \mathrm{ft})$ as it raced $51 \mathrm{~km}(33 \mathrm{mi})$ to the southwest toward New Madrid, Missouri. The fuse plug near New Madrid was blown up on May 3, 2011, to accelerate the return of the floodwater back into the Lower Mississippi River. The frontline levee near
Big Oak Tree State Park was opened with trinitrotoluene (TNT) on May 5, 2011 (figure 1).There was severe damage to most of the 200 building structures, including 75 homes, which were exposed to flowing floodwater. These buildings were damaged when they were partially submerged in 1.8 to $3 \mathrm{~m}$ (6 to $10 \mathrm{ft}$ ) of temporarily stored floodwater, which will be the focus 
of an upcoming article in the Journal of Soil and Water Conservation (Morton and Olson forthcoming).

\section{LEVEE PATCHING OF FUSE PLUGS AND RECONSTRUCTION OF THE FRONTLINE LEVEE}

In the fall of 2011, the USACE began reconstructing the Birds Point and New Madrid fuse plugs (figure 2). Initially, the fuse plugs at blast sites 1 and 2 (figure 1), which were at $18.3 \mathrm{~m}(60.5 \mathrm{ft})$ prior to the explosions, were rebuilt (figure 3) to only $15.4 \mathrm{~m}$ (51 ft) as a result of insufficient federal funds to repair the levees (USACE 2011). The lower levee height was of great concern to floodway landowners who thought their lands were at considerable future risk. When they met with the USACE in the early fall of 2011, the landowners strongly demanded the levee be restored to the original levee height of $18.3 \mathrm{~m}(60.5 \mathrm{ft})$ or $18.9 \mathrm{~m}(62.5$ $\mathrm{ft})$ and noted that the proposed $15.4 \mathrm{~m}$ $(51 \mathrm{ft})$ height would result in flooding every other year based on historic flooding records (NOAA 2012). Later, the USACE obtained additional funds from Congress to rebuild the levee patches (figure 3). Since 1884, the Mississippi River flooding exceeded the $16.7 \mathrm{~m}$ (55 ft) only seven times including the record floods of 1927, 1937, and 2011 (NOAA 2012). The Big Oak Tree frontline levee repair was delayed until after nesting birds in this area left. The frontline levee near The Big Oak Tree State Park was then rebuilt to $16.7 \mathrm{~m}$ $(55 \mathrm{ft})$ in October and November of 2011 to prevent potential flooding in spring of 2012. The top of the frontline levee patch was covered with canvas since it was too late to establish a vegetative cover (figure 3).

In March of 2012, the USACE received US $\$ 22$ million to raise the patched flood-

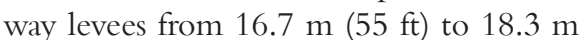
$(60.5 \mathrm{ft})$ at the fuse plugs locations and to $18.9 \mathrm{~m}(62.5 \mathrm{ft})$ at the frontline levee. On May 30, 2012, the USACE released contracts to private contractors to begin raising the three levee patches to original height. A private contractor, who lost the bid due to paperwork problems, protest letter delayed the start of the repairs at Birds Point for about seven weeks. Thanks

\section{Figure 2}

The Big Oak Tree blast site levee before it was repaired in October of 2011 and attached to the $18.9 \mathrm{~m}$ frontline levee.

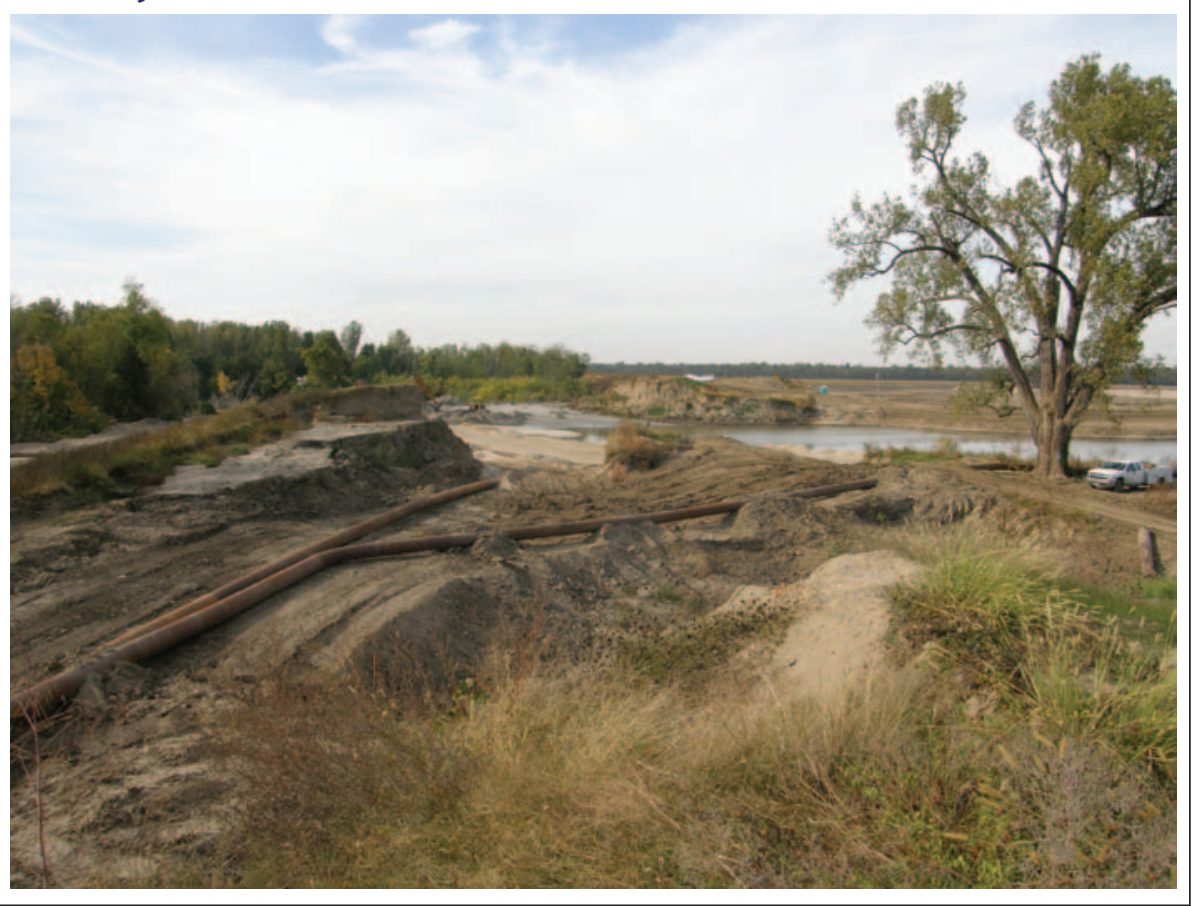

\section{Figure 3}

The site of the third explosion on the frontline levee is located near Big Oak Tree State Park. The levee patch is being constructed where the crater lake extended into agriculture lands.

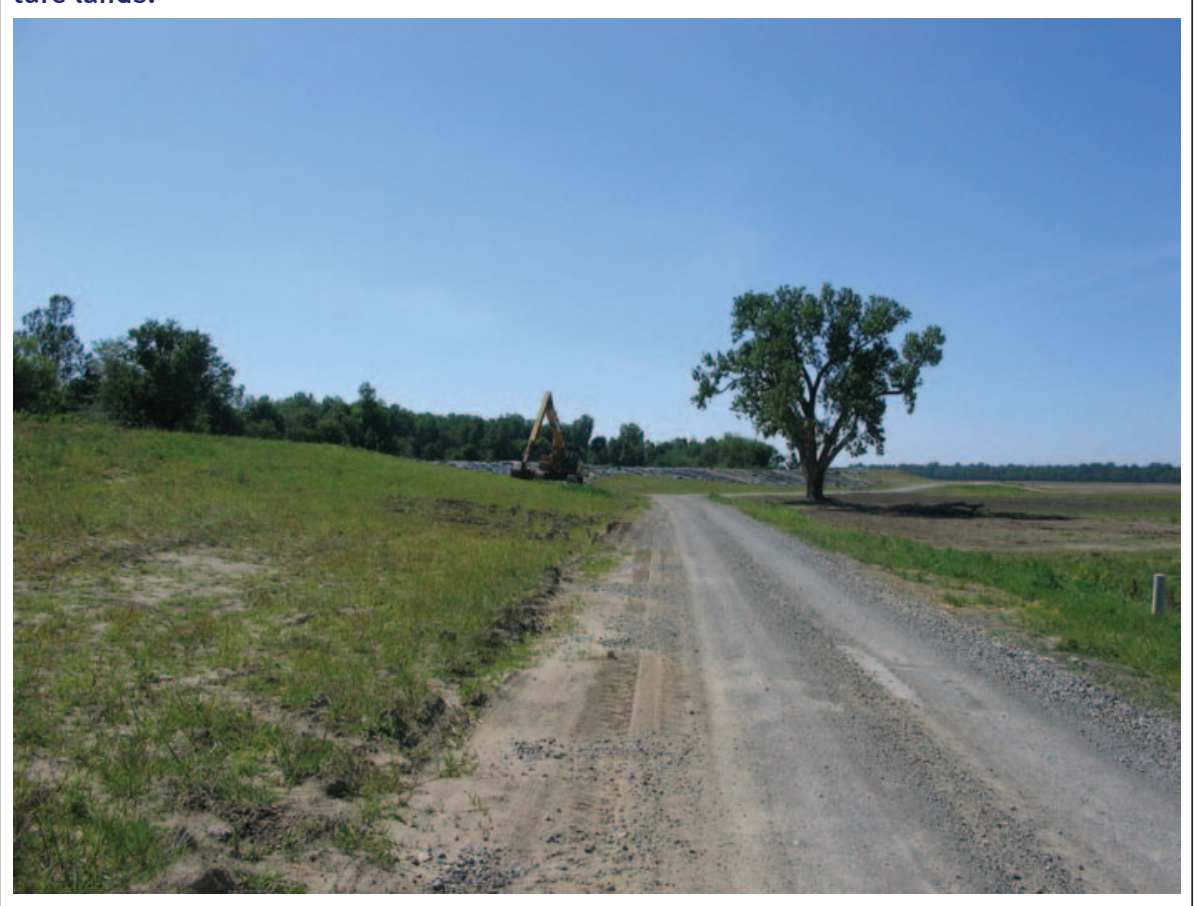

to drier than normal weather, much of the levee work was completed by November of 2012 (Moyers 2012). The USACE filled in the crater lakes and reestablished washed-out roads at the base of the levee, reconnecting levee roads to the west and south (figure 3). 


\section{CRATER LAKE FILLING AND SOIL REPLACEMENT}

The six crater lakes at Birds Point fuse plug levee extended into agricultural lands a total of 3.1 ha $(7.8 \mathrm{ac})$. They were filled in by the USACE and covered with truckedin topsoil in October of 2011 to ready the fields for either winter wheat (Triticum aestivum L.) in fall of 2011 or soybeans (Glycine max [L.] Merr.) and corn (Zea mays L.) in spring of 2012. There were also deltaic sand deposits 0.3 to $1.5 \mathrm{~m}$ (1 to $4.6 \mathrm{ft}$ ) thick and approximately 3 to 20 ha (7.4 to $49.4 \mathrm{ac}$ ) in size that needed to be addressed to prevent a permanent loss of what was previously finer textured agricultural land (Olson 2009; Lowery et al. 2009). This reconstructed soil profile will still be less productive than the original soils. Much of the topsoil came from other levees on smaller tributaries and drainage ditches. The hole in the frontline levee, created on May 5, 2011, by the 3rd explosion (figure 1), let the record high Mississippi River flow back into the New Madrid Floodway. The inflow created an expanded 2 ha (5 ac) crater lake and a 27 ha $(67 \mathrm{ac})$ sand delta to the west in the floodway on top of prime farmlands near the Big Oak Tree State Park (figure 2). The crater lake was partially filled in as the levee was rebuilt to $16.7 \mathrm{~m}(55 \mathrm{ft})$ in November of 2011. It still remained as a slight depression in May of 2012 and was left idle in the 2012 growing season. Part of the sand deposit was removed in October and November of 2011 and spread on the local lanes and roads.

\section{CROP LOSS}

Approximately, 8,094 to 12,141 ha $(20,000$ to $30,000 \mathrm{ac})$ of wheat that was planted in the fall of 2010 drowned before filling with grain. Most of the agricultural lands dried out before July 12, 2011, and to the surprise of most observers, farmers were able to plant 36,424 ha $(90,000 \mathrm{ac})$ of soybeans (Olson and Morton 2012b). Soybeans planted in July rather than June had lower yields. Approximately 12,141 ha $(30,000 \mathrm{ac})$ of low-lying land was under water on June 20,2011, and remained too wet to be planted to soybeans and harvested in 2011 (figure 4). Approximately 6,070 ha $(15,000 \mathrm{ac})$ of these soils dried

\section{Figure 4}

Idle, wet, low-lying soils remained wet on October 24,2011 , or more than five months after the floodway opening and could not be cropped in 2011.

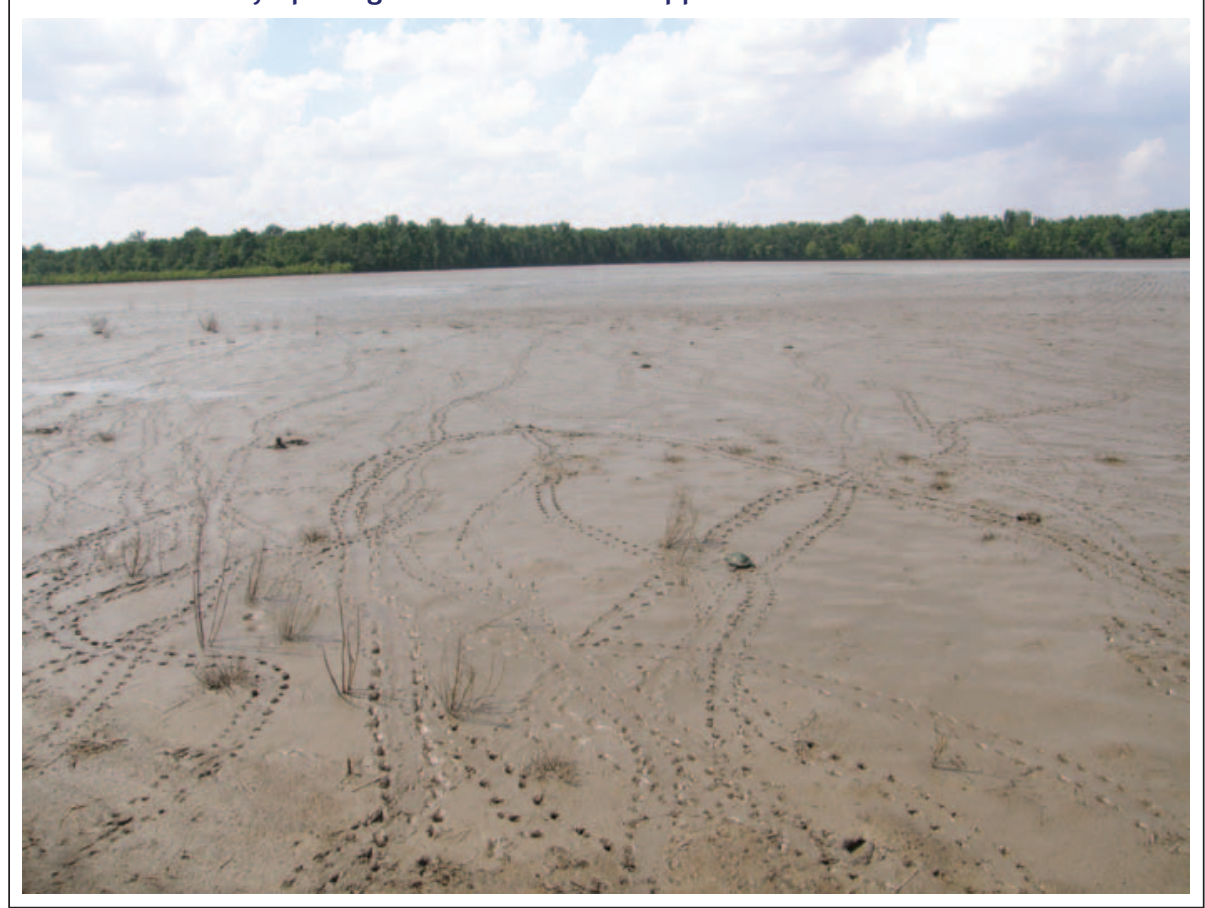

out sufficiently by the fall of 2011 and were planted to winter wheat. The remaining 6,070 ha $(15,000 \mathrm{ac})$ area under water, low lying and with clayey soils (Sharkey silty clay loam and Alligator silty clay [Brown 1977; DeYoung 1924]), had slow permeability and remained idle in 2011. Most of these areas were chisel plowed and disked to mix in the sediment and silt coatings, which helped dry out the soils. These idle areas were planted to soybeans or corn in the spring of 2012 .

Other areas that could not produce a 2011 crop included the 400 ha $(1,000$ ac) of agricultural land adjacent to the Birds Point fuse plug levee and the 200 ha $(500 \mathrm{ac})$ of land adjacent to the Big Oak Tree frontline levee breach. In these two cases, the levee was patched and the crater lakes filled in; topsoil was transported and spread over the six Birds Point crater lakes by November of 2011, but it was too late to plant any crops in 2011. Another area not planted to crops was O'Brien Ridge east of Route 77 (figure 1), encompassing approximately 168 ha (420 ac) of very deep gullies with areas between and adjacent to the gullies not tilled and planted to soybean (Olson and Morton 2012b). One area with 50 ha $(125 \mathrm{ac}$ ) of gully fields (fig- ure 1), located west of Route 77, had the gullies removed by the land owner, initially at personal expense, utilizing mechanized earth moving equipment with some topsoil transported and placed on the soil surface. The land was reshaped in time for winter wheat in 2011 or soybeans and corn planting in the spring of 2012.

The total 2011 crop loss included 8,094 to 12,141 ha $(20,000$ to 30,000 ac) of drowned winter wheat and 12,141 ha $(30,000 \mathrm{ac})$ of low lying areas, which either remained too wet to plant to soybeans in 2011 or, if planted to wheat, did not result in a harvested crop in 2011. About 600 ha $(1,500 \mathrm{ac})$ of agricultural lands, near the blown up levees at Birds Point and Big Oak Tree, had crater lakes which were partially filled in and the thick sand deposit at Big Oak Tree breach was only partially removed. These areas were not reclaimed in time for fall 2011 or spring of 2012 planting. The USDA Risk Management Agency issued a ruling that the induced flooding of the New Madrid Floodway was caused by nature (the heavy rains in Ohio River Watershed) and the flood damages would be covered by claims to crop indemnity insurance as if they had occurred as a result of a natural flooding 
event. USDA Risk Management Agency 2011 payouts to landowners in Mississippi and New Madrid counties (Missouri) for excess moisture/precipitation/rain and flooding totaled almost US $\$ 16.2$ million with almost US\$9.7 million paid for crop damage prior to the May 2011 levee breach (Loy 2012). Sixty percent (US $\$ 8.7$ million) of the payout was for loses to the 2011 corn crop, $23.5 \%$ or almost US $\$ 3.4$ million was for wheat loses, and $16.5 \%$ or almost US $\$ 4.4$ million was for soybean loses (Loy 2012). These payouts are only a portion of the total crop losses and restoration costs associated with the 2011 flooding event. The crop damage estimates by landowners in the floodway have been reported to be as much as US $\$ 42.6$ million to US\$60.6 million in 2011 (Schick 2011).

\section{SEDIMENT DEPOSITS ON LAND AND IN DRAINAGEWAYS AND DITCHES}

The 8,094 to 12,141 ha $(20,000$ to 30,000 ac) of drowned fully grown but not grain filled wheat trapped significantly more sediment (a few centimeters [few inches]) than fields with soybean stubble. More than 30 excavators worked from late May to November of 2011 to remove debris and sediment that was blocking drainage ditches (figure 5) in order to speed up the drainage process and to accelerate the drying out of low-lying areas. The sediment in private drainageways of most qualified land owners was removed with a $75 \%$ cost share from the USDA Farm Service Agency Emergency Services Agency's Emergency Conservation program. It took until October of 2011 for half of the last 6,070 ha $(15,000 \mathrm{ac})$ to dry out sufficiently to allow tractor traffic and planting of wheat in the fall of 2011. The other half of the idle land (figure 4) was eventually tilled to mix in the sediment and to help dry out the fields. These remaining fields were planted to soybeans or corn in 2012. In some places (especially along Route 77), the road ditches were filled with 0.9 to $1.8 \mathrm{~m} \mathrm{(3} \mathrm{to} 6 \mathrm{ft}$ ) of fine sediment and sand. In addition, there were a hundred hectares (hundreds of acres) of thick sand deposits at both the Birds Point and the Big Oak Tree levee breaches, which had to be removed in 2011 and 2012 .

\section{Figure 5}

Two excavators removing sediment from a drainage ditch and spreading it on the stream bank surface.

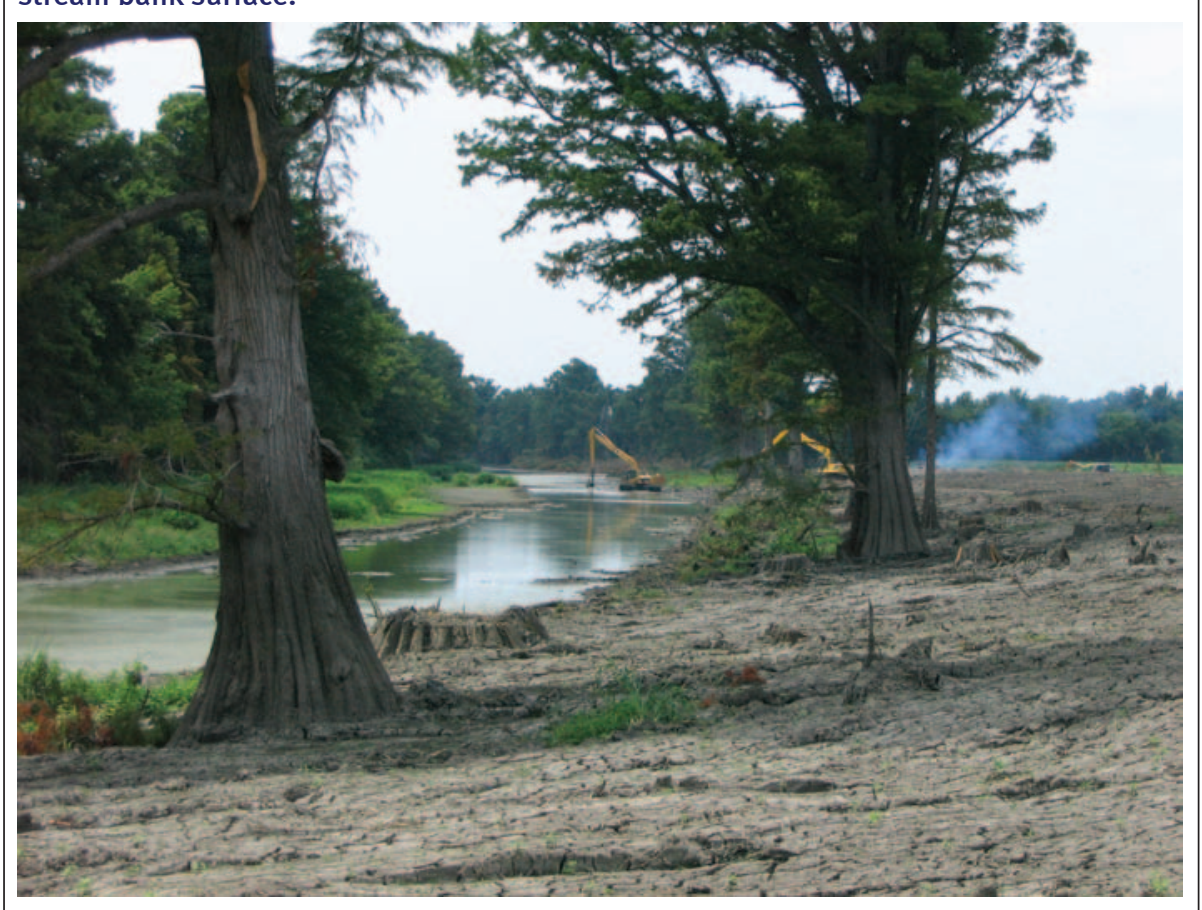

Thin coatings of silt covered much of the 53,824 ha $(133,000 \mathrm{ac})$ floodway. The sediment deposits were much thicker in the drowned wheat fields with extra plant residue. Most of the thin silt and clay deposits were exposed to sunlight with tillage to speed drying and incorporate deposits into the plow layer. Through the Emergency Watershed Protection (EWP) program administrated by the USDA Natural Resources Conservation Service (NRCS) and sponsored by county governments or drainage districts, the sediment depositions in large drainage ditches were removed. Sediment deposition on private farm waterways was removed on a cost share basis by a program administered by the USDA Farm Service Agency with NRCS with US $\$ 3$ million in technical support. Excavators in Consolidated Drainage District 1 of Mississippi County scooped out silt from the drainage ditches (figure 5) and loaded it onto trucks to create ditch banks further down the ditch. The work was accelerated when the president of Consolidated Drainage District No. 1 signed an amendment to an existing cooperative agreement to flood recovery work in the Birds Point-New Madrid Floodway utilizing the USDA NRCS EWP program.
This floodway restoration effort is part of a total US $\$ 35$ million project to clean out $1,400 \mathrm{~km}$ (900 mi) of ditches with 120 excavators and draglines employing more than 200 workers in the Missouri Bootheel bottom lands that extended south to the Arkansas border. Funds were appropriated by Congress through the EWP program. In April of 2012, the USDA NRCS made an additional US\$2.1 million of federal disaster funds available for flood repair work to supplement the US\$0.9 million already committed to the Birds Point-New Madrid Floodway as part of the USDA NRCS EWP program. A total of US $\$ 3$ million funded six repair sites with the drainage district providing US $\$ 335,000$ in matching funds. The new project removed sediment and debris from the drainageways and drainage ditches (figure 5) in the floodway and disposed of some of the excavated materials. Initially, work in spring of 2012 focused on the main ditch, which drained more than 40,000 ha $(100,000 \mathrm{ac})$ into the Mississippi River just east of the town of New Madrid (figure 1). The main ditch goes through the $455 \mathrm{~m}(1500 \mathrm{ft})$ gap between the front line levee and the setback levee, which merges with the town 
of New Madrid frontline levee. Additional excavators worked on the other district ditches. Repairs in the Birds Point-New Madrid Floodway were accelerated in April of 2012 to clean out Ditch 29, the main drainage artery for Consolidated Drainage District 1. Sediment depths were found to be between 0.3 to $2.7 \mathrm{~m}$ (1 to $9 \mathrm{ft})$.

\section{GULLY FIELDS AND LAND SCOURING}

Approximately, 100 ha $(250 \mathrm{ac})$ of land between the main drainage ditch and blast site 3 (figure 1) were scoured as the flooding reached the area via the overflowing main drainage ditch and flowed into the opening of the Big Oak Tree levee. The fine particles (sand, silt, and clay) were carried into the Mississippi River through the frontline opening (figure 1), and fine gravels were left behind and covered the soil surface.

Significant land scouring took place with many hundreds of hectares (many hundreds of acres) of land losing centimeters (inches) of topsoil. Deep gully fields were found $8 \mathrm{~km}(5 \mathrm{mi})$ from the Birds Point levee fuse plug, which released a $3.6 \mathrm{~m}(12 \mathrm{ft})$ wall of water that was initially $2 \mathrm{~km}(1.2 \mathrm{mi})$ wide. The wall of water spread out and covered the $8 \mathrm{~km}$ (5 mi) wide floodway to a $0.9 \mathrm{~m}(3.6 \mathrm{ft})$ depth and ponded in front of the $2.4 \mathrm{~m}$ (8 ft) high O'Brien Ridge. The floodwater flowed over the $0.9 \mathrm{~km}(0.6 \mathrm{mi})$ wide natural levee ridge and then dropped down to lower level bottomlands in a few existing natural waterways. As the water flowed into the waterway, it started to cut into the natural levee, and in one case, the water carved a channel $3.7 \mathrm{~m}$ (12 ft) deep,

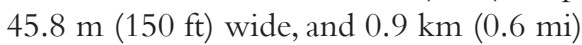
long in first two weeks in May of 2011. After the water cut this huge gully all the way back to the wooded lower bottomland along the ridge, it started cutting into the lower bottomland soil, and the trees on the bottomland fell into the $3.7 \mathrm{~m}(12$ ft) deep gully (Olson and Morton 2011b). The gully walls were $3.7 \mathrm{~m}$ (12 ft) high and vertical. These gully fields dried out quickly and were planted to soybean in 2011 (figure 6), but farmers had to stay out of all the gullies since many still had a meter (few feet) of water in the bottom months

\section{Figure 6}

A soybean crop was planted in 2011 around the gullies, which prevented the farmers from cultivating a hundred hectares of land.

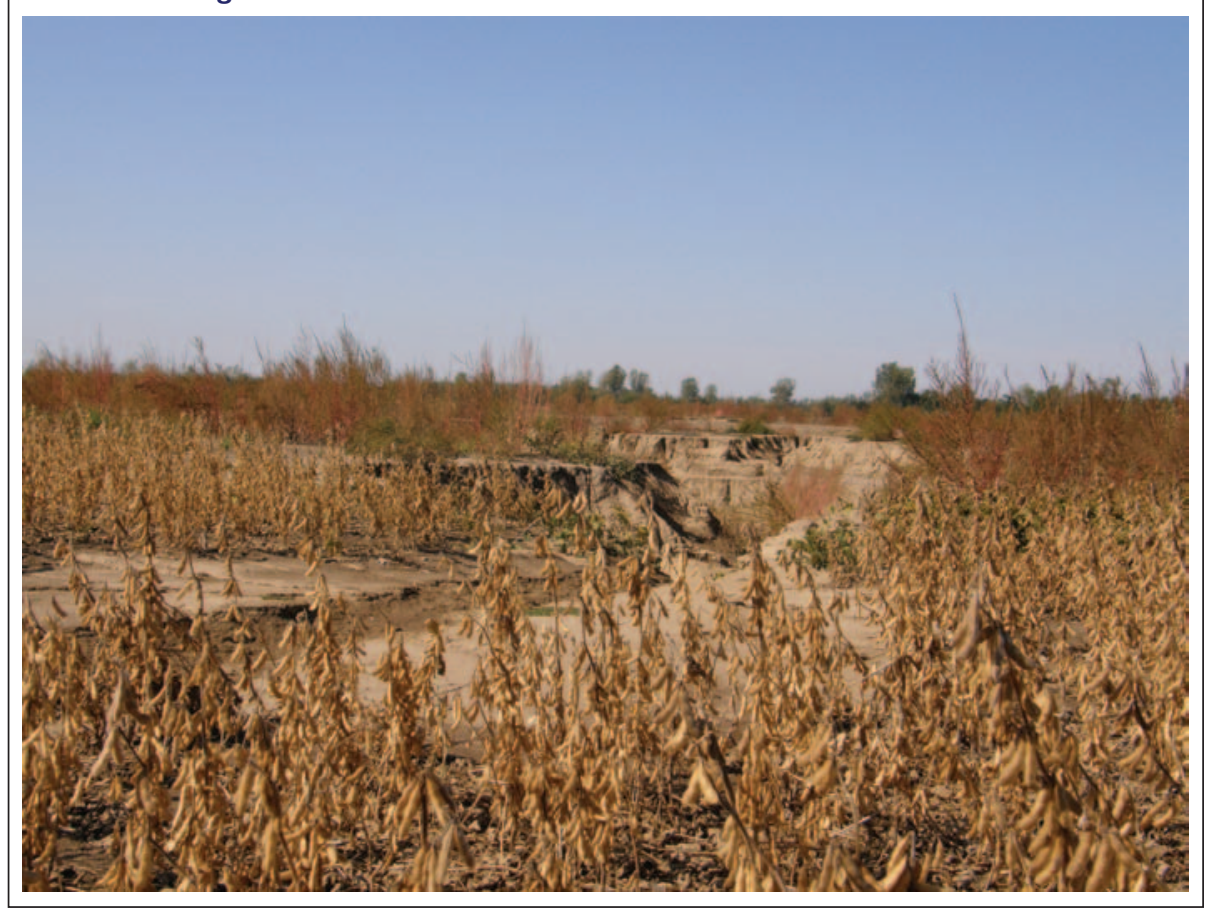

after the flooding. The force of dropping floodwater created these large gullies and removed any road beds and bridges in its path. The O'Brien Ridge main gully fields east of Route 77 (figure 1) were still not reclaimed as of fall of 2012. A landowner did fill in and regrade a small gully field on the south end of O'Brien Ridge near the frontline levee in spring of 2012. The two severed gravel roads were reconnected in fall of 2011. Soybeans were planted around the unreclaimed gully fields in 2012.

The remaining gully fields, especially O'Brien Ridge, will be extremely difficult and costly to reclaim. It is still not clear who will pay the cost to restore land-scoured areas and the O'Brien Ridge gully fields. Initially it appears the landowner will pay the reclamation cost. Reclamation options include attempting to fill in the gullies to the original contour (by bringing in dredge sediments); however, this would take thousands of metric tons of alluvial sediment, which would include parent material, subsoil material, and topsoil. Filling the gully fields in with sediment dredged from the drainage ditches would make the land vulnerable to erosion and degradation during the next use of the floodway.
A second option would be to push the tops of the vertical walls into the gullies to fill in the bottom, which is under water periodically, and then grade the sideslopes and cover with hauled in topsoil to raise the soil organic carbon level of the plow layer. The land could be reshaped with levees and/or grade stabilization structures located on the sideslopes above the waterway. A large culvert under the gravel road would be needed. This approach would still result in the loss of long-term soil productivity and crop yields since the newly created soils will be less productive than the original soils as a result of topsoil and rooting zone having parent material low in soil organic carbon mixed in. This land reclamation effort to restore the land-scoured ridges and gully fields would cost hundreds of thousands of dollars (estimated, no cost analysis preformed) and would still result in lowered soil productivity when compared to the original soil crop yields (Olson and Lang 2000).

A third approach would be to put a 0.9 $\mathrm{km}(0.6 \mathrm{~m})$ large drainage tile through the entire O'Brien Ridge and then bury it with soils materials from the top of the ridges to create a waterway and reshape the sideslopes. A fourth approach would 
be to convert the gully fields to a wetland reserve and/or wildlife habitat. Any future use of the floodway would do less damage to the wetland reserve than would happen if the agricultural use of the gully fields continued.

Another smaller gully field area less than $40 \mathrm{ha}(100 \mathrm{ac})$ and located west of Route 77 (figure 1) was reclaimed by the landowner who brought in earth moving equipment to push the vertical walls into the gullies, grade and shape the fields, and transport in topsoil for spreading on the reclaimed fields. These sloping fields will be more erosive in the future than the original nearly level fields. Another farmer reported more than 130 ha $(320 \mathrm{ac})$ of fields so severely scoured and/or so much sediment deposition that they could not be planted in spring of 2011. After reclamation in summer of 2011, he planted wheat in the fall.

When federal officials signed a new agreement for flood repair work, most of the funds were directed for sediment removal. A USDA NRCS state conservationist indicated that many fields have tremendous numbers of gullies and land scouring and will need to be reshaped. The USDA NRCS may devote funds, if any remain from the sediment removal project, to reclamation of the land scoured and the gully field areas. It is not yet resolved how the gully fields, including the 12 different tracts on O'Brien Ridge, will be addressed, or the timing (fall 2012 or spring 2013) or at whose expense. In March of 2012, 140 farmers located in the Birds Point-New Madrid Floodway filed a lawsuit in an attempt to get the USACE to pay for soil damages. Since the two gully fields (figure 1) are located on about 13 tracts, it appears land scouring impact and sediment deposition on other farmland was included in soil damages claim. Crop losses partially covered by crop insurance were not included in the suit. A federal judge ruled in May of 2012 that the taking of land claim needed to be dropped since the floodway use of land occurred only twice in 83 years (1937 and 2011).

\section{CONCLUSIONS}

The bottomland soils of the New Madrid Floodway are some of the most productive cropland in the state of Missouri, in the North Central region, and in the nation. Reclamation efforts subsequent to the flood have been substantive. There were very significant crop losses in 2011. Crop insurance provided replacement income for farmers who had purchased insurance. Even if the gully fields are eventually reclaimed, the regraded soils will have more parent material mixed into the root zone, which will likely lower the crop yields and productivity of the soils due to the lower soil organic carbon content, greater slope, and lack of topsoil and subsoil materials in the root zone. Most of the damaged agricultural lands have been reclaimed, tilled, and planted to crops in fall 2011 and 2012, except for part of the big gully fields on O'Brien Ridge, the filled in Birds Point and Big Oak Tree crater lakes, and the remaining deltaic sand deposits. Public dollars helped to cover the US $\$ 16.2$ million in crop insurance payments, US $\$ 10$ million for the USACE to repair and raise the levees to $15.4 \mathrm{~m} \mathrm{(51}$ $\mathrm{ft})$ and then to $16.7 \mathrm{~m}(55 \mathrm{ft})$, and eventually another US\$22 million to restore the damaged levees back to the original height. One hundred and forty farmers in the floodway have sued the Federal government for soil damages, but the value has yet to be determined. While the full price tag for saturated soils, excess rain, internal flooding, and flooding from the breaching of the frontline levee has not yet been computed, the 2011 flood costs to the New Madrid Floodway and Cairo area are likely to substantively exceed US\$101.2 million.

\section{REFERENCES}

Brown, B.L. 1977. Soil Survey of New Madrid County, Missouri. Washington, DC: USDA Natural Resource Conservation Service.

Camillo, C.A. 2012. Divine Providence: The 2011 Flood in Mississippi River and Tributaries Project. Vicksburg, MS: Mississippi River Commission.
DeYoung,W. 1924. Soil Survey of Mississippi County, Missouri. Washington, DC: USDA Bureau of Soils.

Lowery, B., C. Cox, D. Lemke, P. Nowak, K.R. Olson, and J. Strock. 2009. The 2008 Midwest flooding impact on soil erosion and water quality: Implications for soil erosion control practices. Journal of Soil and Water Conservation 64(6):166A, doi:10.2489/jswc.64.6.166A.

Loy, A. 2012. Summarizing Crop Indemnity for the New Madrid Floodway from USDA Risk Management Agency data. Ames, IA: Iowa State University. www.rma.usda.gov/data/cause.html.

Morton, L.W., and K.R. Olson. Forthcoming. Birds Point-New Madrid Floodway: Redesign, reconstruction, and restoration. Journal of Soil and Water Conservation 68(2).

Moyers, S. 2012. Flood of 2011 anniversary: Floods scars remain a year later. Southeast Missourian, May 2, 2012.

NOAA (National Oceanic and Atmospheric Administration). 2012. Historic crests. Cairo, IL: National Weather Service, Advanced Hydrologic Prediction Service.

Olson, K.R. 2009. Impacts of 2008 flooding on agricultural lands in Illinois, Missouri, and Indiana. Journal of Soil and Water Conservation 64(6):167A-171A, doi:10.2489/jswc.64.6.167A.

Olson, K.R., and J.M. Lang. 2000. Optimum crop productivity ratings for Illinois soils. University of Illinois, Agriculture, Consumer and Environmental Sciences, Bulletin 811, 36p. Urbana, IL: Office of Research.

Olson, K.R., and L.W. Morton. 2012a. The effects of 2011 Ohio and Mississippi River Valley flooding on Cairo, Illinois, area. Journal of Soil and Water Conservation 67(2):42A-46A, doi:10.2489/ jswc.67.2.42A.

Olson, K.R., and L.W. Morton. 2012b. The impacts of 2011 induced levee breaches on agricultural lands of Mississippi River Valley. Journal of Soil and Water Conservation 67(1):5A-10A, doi:10.2489/jswc.67.1.5A.

Schick, A. 2011. Farmland behind Birds Point levee recovers faster than expected. Columbia Missourian, November 4, 2011.

USACE (US Army Corps of Engineers). 2011. Great Flood of '11. Our Mississippi. Rock Island, IL: US Army Corps of Engineers. http://www.mvs. usace.army.mil/Our\%20Mississippi/ourmississippi_su11_lowres.pdf. 